\title{
Identity, feeling of belonging and collective action in localized agrifood systems. Example of the Serrano cheese in the Campos de Cima da Serra, Brazil
}

\author{
Carine Pachoud ${ }^{1,2,3, *}$ \\ ${ }^{1}$ Institute of Geography, University of Innsbruck, Innrain 52f, 6020 Innsbruck, Austria \\ 2 CIRAD, UPR GREEN, 34398 Montpellier, France \\ ${ }^{3}$ GREEN, CIRAD, Univ. Montpellier, Montpellier, France
}

\begin{abstract}
The study is aimed at linking social representations of identity and feeling of belonging to territory of farmers, to their degree of involvement in collective action within localized agrifood systems (LAS). The study was conducted with producers' families producing Serrano cheese, in the mountains of the Campos de Cima da Serra, in southern Brazil. Collective action for the valorization of the Serrano cheese relied on the producers' associations, which are the only form of collective organization. Fifty-four families were selected according to their level of involvement in collective action. First, we used a quantitative approach called the free word association, analyzed by Factorial Correspondence Analysis. Second, we asked closed questions to the producers to assess their feeling of belonging. We showed that the content of the social representation reflected the participation of producers in collective action. Producers who put forward the typicality of the cheese, the territory and their identity, were the most engaged in the associations. On the other hand, producers not involved in associations put forward the difficulties of their activity. In this sense, it appears valuable to encourage discussion between the different producers according to their level of involvement to build common representations that favor collective action for the defense and valorization of the Serrano cheese. Nonetheless, most producers tended to show a high feeling of belonging which could form the basis for discussion. However, collective action in the LAS follows a top-down model led by extension services, in which the producers need to be integrated in a more participatory governance to lead more efficient projects.
\end{abstract}

Keywords: identity / feeling of belonging / collective action / localized agrifood systems / mountain cheese

Résumé - Identité, sentiment d'appartenance et action collective au sein des systèmes agroalimentaires localisés. Exemple du fromage Serrano dans les Campos de Cima da Serra, Brésil. L'étude a pour objectif de relier les représentations sociales de l'identité et le sentiment d'appartenance au territoire d'agriculteurs à leur degré d'implication dans l'action collective au sein de systèmes agroalimentaires localisés (SYAL). L'étude a été réalisée auprès de familles de producteurs produisant du fromage Serrano dans les montagnes des Campos de Cima da Serra, au sud du Brésil. L'action collective pour la valorisation du fromage Serrano s'appuie sur les associations de producteurs, qui constituent aujourd'hui la seule forme d'organisation collective. Cinquante-quatre familles ont été sélectionnées en fonction de leur degré d'implication dans l'action collective. Premièrement, nous avons utilisé une approche quantitative appelée association libre de mots, analysée par une analyse factorielle des correspondances. Deuxièmement, nous avons posé des questions fermées aux producteurs pour évaluer leur sentiment d'appartenance. Les résultats ont montré que le contenu de la représentation sociale reflétait le niveau d'engagement des producteurs dans l'action collective. Ainsi, les producteurs qui ont mis en avant la typicité du fromage, du territoire et de leur identité étaient les plus investis au sein des associations. En revanche, les producteurs non engagés au sein d'associations mettaient en avant les difficultés de leur activité. Ainsi, il semble utile d'encourager la discussion entre les différents producteurs en fonction de leur niveau d'implication afin de construire des représentations communes favorisant l'action collective pour la

*Corresponding author: carine.pachoud@hotmail.fr 
défense et la valorisation du fromage Serrano. Néanmoins, la plupart des producteurs ont montré un fort sentiment d'appartenance, ce qui pourrait ainsi servir de base à la discussion. Cependant, l'action collective au sein du SYAL suit un modèle top-down, menée par les services de vulgarisation. Il est donc nécessaire d'intégrer les producteurs dans une gouvernance davantage participative afin de mener des projets plus efficaces.

Mots clés : identité / sentiment d'appartenance / action collective / systèmes agroalimentaires localisés / fromage de montagne

\section{Introduction}

In a context of growing standardization of cultures and human mobility caused by globalization, we are seeing a strengthening of identities and the feeling of belonging in many territories (Di Méo, 2016). It is the case for most localized agrifood systems (LAS) producing mountain cheese, where territories remain strong anchor points (Chalas, 2009). The notion of LAS, based on a territorial approach, highlights the typicality and singularity of products and the know-how and identities of the communities (Muchnik, 1996; Fournier, 2008; Cañada and Muchnik, 2011). The territorial dimension is often an essential component of the process of identity building of communities in LAS, especially for the producers (Fournie, 2016). Indeed, territorial referents contribute to create or consolidate their identity by giving it a material, concrete and also an ideal support rich in images and symbols (Di Méo, 2016). The sense of belonging, called also territoriality (Brunet, 1990), appears as a subjective element of the identity and its measure allows assessing this land base (Di Méo and Buléon, 2005). In such LAS, many actions are done to promote the products, where particularities of the territory, know-how and people become more and more a specific resource, as shown by the rising use of labels linked to the origin and the quality of the products (Muchnik et al., 2008; Pecqueur, 2009). In this way, we hypothesize that shared representations of identity and a strong sense of belonging to the territory facilitate collective action for the valorization of the products. Collective action refers to "the action taken by a group (either directly or on its behalf through an organization) in pursuit of members' perceived shared interests" (Marshall, 1998). In LAS, collective action can rely on the actions of diverse organizations, such as producers' associations in the case of this study.

The study was conducted in the Campos de Cima da Serra in southern Brazil. This mountain region holds the Serrano cheese production, a traditional raw milk cheese, produced by family farmers. Today, we observe an important increase in the demand of consumers for Serrano Cheese (Ambrosini, 2007), especially for young cheese of less than thirty days of maturation. However, this chain remains informal and cheese sales have become illegal, with producers being prosecuted for marketing their cheeses. Indeed, this product does not meet the sanitary standards for raw milk cheese because the Brazilian legal framework does not authorize the selling of raw milk cheese with less than sixty days of maturation. Also, national hygiene standards, adapted to big dairy industries, are incompatible with the reality of small-scale and artisanal production. In this context of informality, collective action and cooperation between the producers became necessary firstly for the defense and the valorization of the Serrano cheese and secondly to convince the food safety policymakers to open new ways for their cheese production.

The study aimed at linking the social representations of the identity and the feeling of belonging to the territory of the Serrano cheese producers to their motivation to engage in collective action. Indeed, to our knowledge there is little research on the link between social representations and collective action and it offers a promising line of research to better understand collective action processes. Our study attempts first to analyze the contents of the representations of the identity of Serrano cheese producers and to measure their sense of belonging to the territory. Second, it seeks to determine which social representations lead to a higher engagement in collective action.

\section{Social representations: a useful concept to interpret identities}

\subsection{Definition of social representation}

Social representation is a social construction, common and shared, of reality. Jodelet (1989) defines representation as "a form of knowledge, socially elaborated and shared, with a practical aim and contributing to the construction of a common reality to a social ensemble". It does not correspond to an objective vision of reality but it is a socio-cognitive construction of it. This subjective appropriation of reality has an individual and collective dimension. These are the results of a set of specific social interactions shared by individuals of common categories. Social representations are built on cognitive processes, which depend on social conditions, cultural heritage and personal experiences. There are different representations for the same object according to the individuals of different populations or of the same population but with different characteristics (practices, resources, etc.), forming different groups of mental belonging (Michel-Guillou and Ehrlich, 2005). Abric (1994) defined four functions of representation in the dynamics of social relations: knowledge that explains reality; orientation that allows orienting the behaviors; justification of the positions and behaviors; and identity that allows the group to maintain its specificity. In fact, social representations contribute to the construction of individual and social identities (Moliner, 1993).

Research on social representations has highlighted a certain structure between the elements of the content (Abric, 1994). First, the central core integrates structural constants. These are implicit elements which determine the meaning of the representation and ensure compliance with the norms and 
values of individuals within the social groups (Moliner, 2001). These elements provide stability of the representation over time. Then, peripheral elements are organized around this core. They play a role of interface between the central core and the reality. They allow the representation to adapt more easily to changes and preserve the central core of external influences. Nonetheless, social representations are dynamic, it means that they can evolve over time. Flament (1994) distinguished between reversible and irreversible situations, depending on whether a return to old practices is perceived as possible or not. If the situation is reversible, only the elements at the peripheral level will change. Whereas if the situation is irreversible, the social representation will be transformed. Flament (1987) used a set of empirical observations to propose a model to represent theses dynamics. For him, practices are the main sources of transformation. Experimental studies are most often carried out via the theory of commitment (Kiesler, 1971). Moliner et al. (1995) showed that committing individuals in a context of freedom could bring important structural changes, both at the central and peripheral level.

\subsection{The couple territory/territoriality to express identities}

The concept of territory has gained a renewed interest in the last thirty years, especially in French geography (Brunet, 1990; Di Méo and Buléon, 2005). Territory, defined as “a developed area, socially constructed, culturally labelled and institutionally regulated" (Lopez and Muchnik, 1997), is seen as a deliberate appropriation of a geographical location (Brunet, 1990; Brunet et al., 1992). This appropriation is at the same time economic, ideological and political (social therefore) (Di Méo, 1998). It is the result of actions of localized social groups (Brunet, 1990), and who assign a specific representation of themselves, their history, their singularity, therefore their identity (Di Méo, 1998; Di Méo and Buléon, 2005). Thus, territory is often a central component of identities (Di Méo, 2016).

Territory displays a triple nature as political space, lived space and substance of all action (Di Méo, 2008, 2014). Indeed, it combines the concrete and material dimensions, those of objects and spaces, those of social practices and experiences of everyday life and action, with the ideal dimensions of representations and powers (Di Méo and Buléon, 2005). Nonetheless, territory is often more abstract, ideal, lived and felt than visually located (Brunet, 1990), in which the representations constitute in reality the true producers of territories (Di Méo and Buléon 2005; Di Méo, 2016). Representations are identified by mediators (symbols, images, memories, etc.), embedded in objects, landscapes and places and built over long periods of time (Di Méo, 1998).

However, the notion of territory appears more and more insufficient to analyze the complexity and the dynamics of societies in their relation to space. The semantic blur and the polysemy of the concept in which the political dimension is often the only retained dimension, creates confusion and tends to discredit it as a scientific object (Di Méo, 2016). The notion of territoriality pretends to exceed these limits (Chalas, 2009). Territoriality is defined as "a system of relationships that a community, and hence an individual who belongs to it, maintains with externality and/or otherness thanks to the help of mediators" (Raffestin, 1982). In other words, territoriality reveals the way in which everyone creates their relationship with the spaces they practice, represent and identify with (Di Méo, 2016), which is nothing other than the feeling of belonging (Brunet, 1990). It represents the effort of the individuals and communities to combine the three dimensions of the territory. So, territorialities express personal and collective identities, produced by territorial representations and expressed through identity mediators (Brunet, 1990; Di Méo and Buléon, 2005). These identities result from an interactive relationship with others in a social and spatial context. Their function is to make normal, logical and necessary the feeling of belonging to a group and a territory. It is the mean of legitimizing a group in a territory from which it will give material, ideal and symbolic resources. They form the major ideal link between human beings, their societies and their spaces (Di Méo and Buléon, 2005; Di Méo, 2016).

\section{Materials and methods}

\subsection{The Serrano cheese and the Campos de Cima da Serra}

The Serrano cheese is a traditional raw milk cheese, produced as a by-product of beef cattle farming in the Campos de Cima da Serra in the Rio Grande do Sul and in the Santa Catarina states. Sixteen municipalities within the state of Rio Grande do Sul and eighteen in the state of Santa Catarina produce artisanal Serrano cheese, together making up the Campos de Cima da Serra (Fig. 1).

Livestock farming is the prime economic activity in the area (IBGE, 2018). There are about two thousand producer families of Serrano cheese and for most of them cheese making is the principal economic activity (more than $50 \%$ of the revenue). More than $90 \%$ of the farms are small-scale family systems. The most common production system is an extensive mixed dairy-beef breeding; with dairy and beef cattle simultaneously on the same farm. Only a few cows in any herd are milked for producing cheese, others are left to provide milk for the calves to produce beef. The herds graze on the natural pastures all year round, supplemented by temporary grazing on improved artificial pastures. Only $3 \%$ of the farms producing artisanal Serrano cheese are considered as intensive farming, it means dairy system without beef production (Ambrosini, 2007). Table 1 presents the size and production per farm of a random sample of sixty-seven families producing Serrano cheese in the Campos de Cima da Serra.

However, the Brazilian legislation does not authorize marketing raw milk cheese with less than sixty days of maturation since law $\mathrm{n}^{\mathrm{o}} 1.283$ came into force in 1952 through regulation $\mathrm{n}^{\mathrm{o}} 30.691$ (Presidency of the Republic of Brazil, 1950, 1952). Most of Serrano cheese producers do not respect this restriction because consumers prefer young cheese over mature, and hence sell their products within less than thirty days, which makes the sales illegal (Cruz, 2012). Moreover, the sanitary norms in Brazil for dairy products do not consider the specificities of artisanal production, which are subject to the same sanitary standards and facilities as big dairy industries. Thus, it is impossible for small-scale farmers to comply with current legal standards because of the high costs 


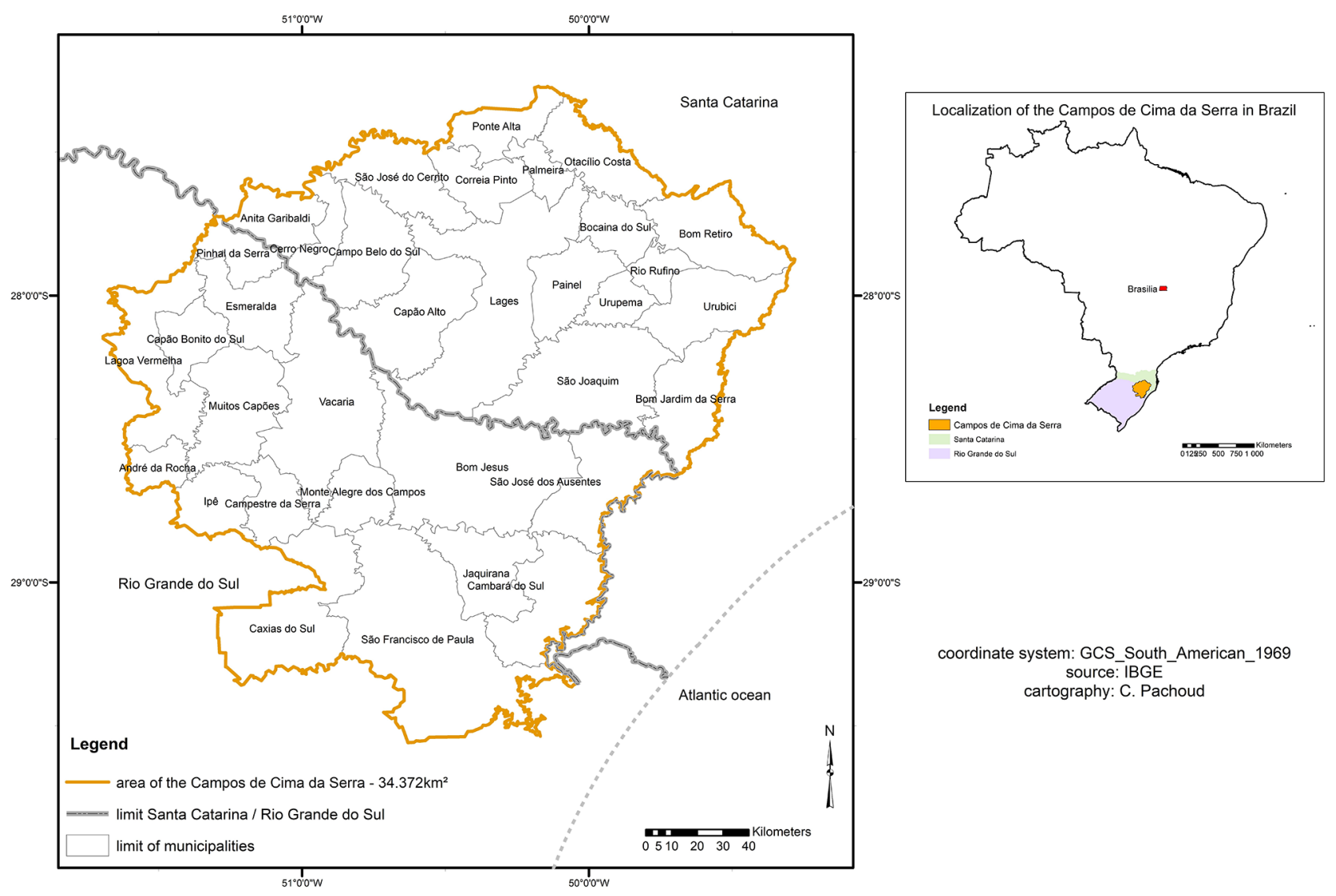

Fig. 1. Geographical area of the Campos de Cima da Serra.

Fig. 1. Zone géographique des Campos de Cima da Serra.

Table 1. Average production and size of the farms producing Serrano cheese.

Tableau 1. Production et taille moyenne des exploitations produisant du fromage Serrano.

\begin{tabular}{lrrr}
\hline & Average & Minimum & Maximum \\
\hline Number of cattle & 90.6 & 14.0 & 800.0 \\
Number of cows milked & 14.4 & 3.0 & 40.0 \\
Milk production (L milk/cow/day) & 8.0 & 2.0 & 20.0 \\
Cheese production (kg cheese/day) & 10.5 & 2.0 & 70.0 \\
Total area (ha) & 132.2 & 6.5 & 980.0 \\
Area of natural pastures (ha) & 96.7 & 3.0 & 90.0 \\
Area of improved pastures (ha) & 17.5 & 2.0 & 70.0 \\
\hline
\end{tabular}

of adaptation to food safety rules. Further, producers claim that the high standards have a negative impact on artisanal characteristics of the cheese, for example, as they are required to replace wooden molds with plastic ones. Besides, the illegality of sale, production of this cheese offers the potential for greater health risks for the consumer, as there is no sanitary control (Cruz, 2012).

In Brazil, regulation systems exist on different scales. First, the municipal inspection service (SIM) establishes and controls the sanitary norms for production and sale of the Serrano cheese, but only for mature cheese, ripened for more than sixty days, within the area of the municipality. The inspection veterinarians employed by the prefectures of the municipalities control the health of the herd and the adequacy of the infrastructures. Today, less than twenty families have the SIM certification. Second, at the state level the law in each state was approved in 2016 and the decree was approved in 2017 in Santa Catarina and in 2018 in Rio Grande do Sul. However, still no producer has the certification to sell cheese within the state areas. Third, at the federal level there is still no legislation authorizing the Serrano cheese sales in all the country. In this context of informality, the majority of the artisanal Serrano Cheese is sold locally by direct sales to consumers or in small markets of the region (Cruz, 2012). Also, growing tourism in the region offers the potential of a new market opportunity for the producers.

In order to act for the defense and the valorization of the Serrano cheese, the first forms of collective organization emerged in the last decade through the creation of four producers' associations spread in twenty-three of the thirtyfour municipalities. Their creation was mostly an initiative coming from the municipality extension services (EMATERRS in Rio Grande do Sul and EPAGRI-SC in Santa Catarina). The first association of Serrano Cheese Producers - APROCAMPOS -, which gathers the municipalities of São José dos Ausentes and Bom Jesus, was created in September 2010. There are currently forty-two family members. Then, APROJAC was created in 2012 in the municipality of 
Jaquirana. In 2017 the municipality of Cambará do Sul decided to join the association. Currently there are twenty-six family members. Then, in 2013, the APROSERRA was created, grouping the eighteen municipalities of Santa Catarina state. Today, more than seventy families are members of the association. Lastly, APROSÃOCHICO was created in 2016 in the municipality of São Francisco de Paula, today only six families producing Serrano cheese are members of the association. So, in Rio Grande do Sul, there are three associations spread in five of the sixteen municipalities, whereas in Santa Catarina, there is only one association gathering the eighteen municipalities. The existence of the associations has resulted in successful actions. First, the state laws and decrees were approved in 2016 in Santa Catarina and 2017 in Rio Grande do Sul for the marketing of Serrano cheese within the state areas. Then, state or private institutions like banks gave low interest loans to assist families who wanted to build farm dairies. Also, the protected designation of origin "Campos de Cima da Serra" was required to the National Institute of Industrial Property in August 2017, in order to protect the artisanal Serrano Cheese and recognize the typicality of this cheese, the territory and the know-how of production. Certification entailed four previous stages of research led by the extension services: historical recovery of Serrano cheese production; market and supply-chain assessment; product and process profiling; and characterization of the cheese's physical, chemical, sensory and microbiological properties (Vitrolles, 2011; Vieira and Dortzbach, 2017).

\subsection{Data collection}

Data were collected through three sessions of fieldwork in February 2017, August/September 2017 and March 2018. The sample of interviewed producers was defined at the beginning of the first fieldwork. We first selected six of the twenty-three municipalities where producer associations were located in order to obtain interviews from producers who were members of the four different associations. The municipalities are São José dos Ausentes and Bom Jesus for the APROCAMPOS association; Jaquirana for the APROJAC association; São Francisco de Paula for the APROSÃOCHICO association and Lages and Painel for the APROSERRA association. The sample was defined thanks to the help to the extension agents of the six municipalities. We chose the extension services because it is the only institution which knows most of the producers as it is the only one which reaches them direct on the farm. They also attend regular association meetings and activities thus have a good knowledge of the level of involvement of each producer members. The extension agents provided the contact details of interviewees according to four different degrees of involvement previously defined, regardless of their production system. In total we interviewed fiftyfour producer families direct on the farm. For twenty-three of the families interviewed, the woman and the man were present together; for seventeen interviews only the woman was present; and for fourteen only the man.

The four categories of involvement degree were the following:

- "important": corresponded to producers' families who are member of a producers' association and participate in every monthly meeting. The producers can be member of the board of direction or not. The attendance is important for this category. Fourteen producers' families were in this group;

- "medium": referred to producer members of an association, who sometimes miss monthly meetings. Producers of this group are not members of the board of direction. This group gathered eleven families;

- "little": corresponded to producer members of an association, little engaged who are little present in monthly meetings. Fifteen families were in this category;

- "no": referred to producers who are not involved in any associations or who left the association. Fourteen families were in this group.

\subsection{Word Association Method through Factorial Correspondence Analysis (FCA)}

The word association method, developed by Ehrlich and Dervin (1999), is widely used by researchers to identify the content of social representations (Michel-Guillou and Ehrlich, 2005). This method is based on a questioning from an inductive word or a set of words, where each individual must indicate all the words or expressions that spontaneously come to their mind from this inductive word. The spontaneous nature of this phase allows rapid access to the elements constituting the semantic universe of the studied objects and thus to obtain the content of the representation (Abric, 2003). The ease of use and ease of understanding by the people explain why we chose to use this methodology in our study; which allow applying the tool to a wide range of individuals. Moreover, according to Ehrlich et al. (1997), the use of oral discourse seems to be one of the most appropriate forms for the study of social representations.

For this study, the inductive set of words was "identity of a producer of Serrano cheese". We asked the question: "could you cite up to ten words or expressions which characterize the identity of a producer of Serrano cheese according to you?" Nonetheless, the multitude of induced words cannot be submitted directly to the statistical method called Factorial Correspondence Analysis (FCA). We must first gather the words of the same meaning or semantically close under a common term. From these semantic groups, the FCA can be conducted to determine perceptions of the producers on the identity of a Serrano cheese producer. The FCA defines categories gathering individuals according to their affinities concerning the perception of each representation. The different categories were analyzed together with the involvement level in collective action of the producers. Data was analyzed with $\mathrm{R}$ version 3.5.1 using the FactoMineR extension dedicated to FCA (Husson et al., 2018).

\subsection{Feeling of belonging to territory}

Regarding the assessment of the feeling of belonging we asked the fifty-four producer families, the two following closed questions:

- "Do you imagine living all your life in the Campos de Cima da Serra?" to which the producers could answer by "yes", "no", "I do not know";

- "Are you proud of your region?" to which the producers could answer by "yes", "no", "moderately". 
Table 2. The different semantic groups with the most frequent induced words and the number of words according to the level of involvement in associations of the 54 producers' families.

Tableau 2. Les différents groupes sémantiques avec les mots induits les plus fréquents et leur nombre suivant le degré d'implication dans les associations des 54 familles de producteurs.

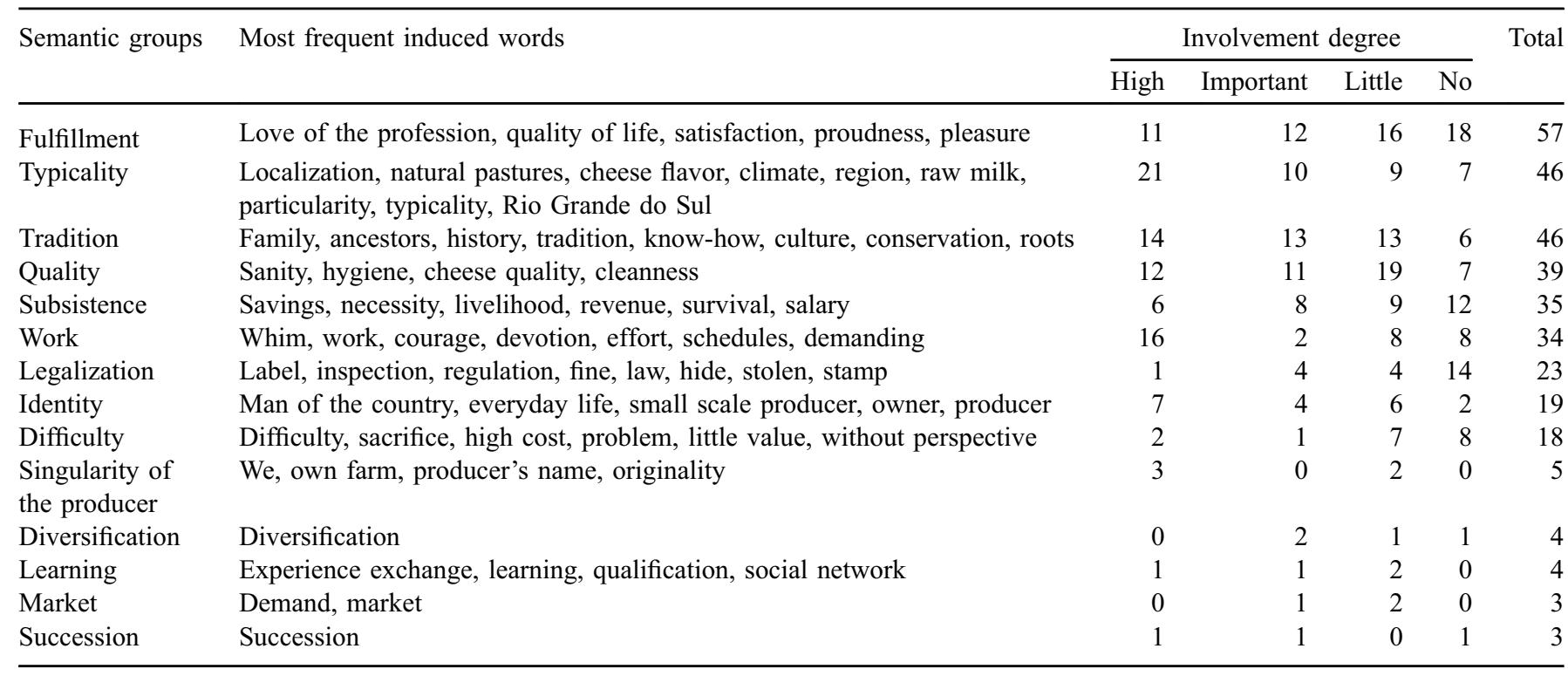

\section{Results}

\subsection{Word association method through Factorial Correspondence Analysis (FCA)}

We obtained a total of 336 words from the fifty-four producers, it means an average of 6.2 words per family (ranged from 3 to 10). The different semantic groups, the most frequent induced words and the number of words according to the involvement degree in associations of the producers are presented in Table 2. The induced words with a low frequency of appearance (less than five) were removed for the FCA in order to obtain more robust results. This corresponds to the terms "market", "singularity of the producer", "learning", "succession" and "diversification". At the end, we had 317 words for the FCA.

The FCA was preceded of a $\mathrm{Khi}^{2}$ test to test the independence of the two variables "representations" and "level of involvement in the associations". We found that the representation of the identity of Serrano cheese producers depends on the level of involvement in collective action of the producer $\left(\mathrm{Khi}^{2}=54.7, f=24, p<0.05\right)$. The result of the FCA is presented in the Figure 2.

Here, the objective is not to interpret the axes but to identify the producers' categories according to their representations. Nonetheless, it is important to note that the categories are not fixed and can overlap, but the idea is to represent the categories that are most representative of the ways of thinking. First, we observe an opposition between each category of involvement level of the producers, which are spread in each part of the graph. More precisely, producers a lot engaged represent themselves through the typicality of their cheese and their territory as well as their well-marked identity, but also by the need of devotion to realize their profession. All the words related to territory were gathered in the semantic group "typicality" and only occurred in this group of producers. Then, for the producers moderately involved in collective action, the sanitary quality of the cheese and the maintenance of the traditions are important elements of their representations. After that, regarding the little involved producers, the fulfillment in their occupation is a central point of their representation; nonetheless they consider the Serrano cheese production as a subsistence activity. Last, producers who are not involved in associations have a negative perception of their cheese activity; they mentioned mostly the difficulties of the work and the illegality issue.

\subsection{Feeling of belonging}

Most of the producers showed a high feeling of belonging, whatever their level of involvement in collective action. Indeed, the large majority of the producers (fifty-three of fiftyfour) answered that they want to stay in the region and are proud of it. Just one family set them apart, answering "I don't know" to the question related to the future in the region and "moderately" to the question related to the proudness of the region.

\section{Discussion}

The study showed that representations of the Serrano producer identity depended on the level of involvement in producers' association. The associations are today the only organization supporting collective action between actors of the LAS to defend and valorize the Serrano cheese. For the most involved ones, the typicality of the Serrano cheese, the territory and their identity are central in their representation. This 


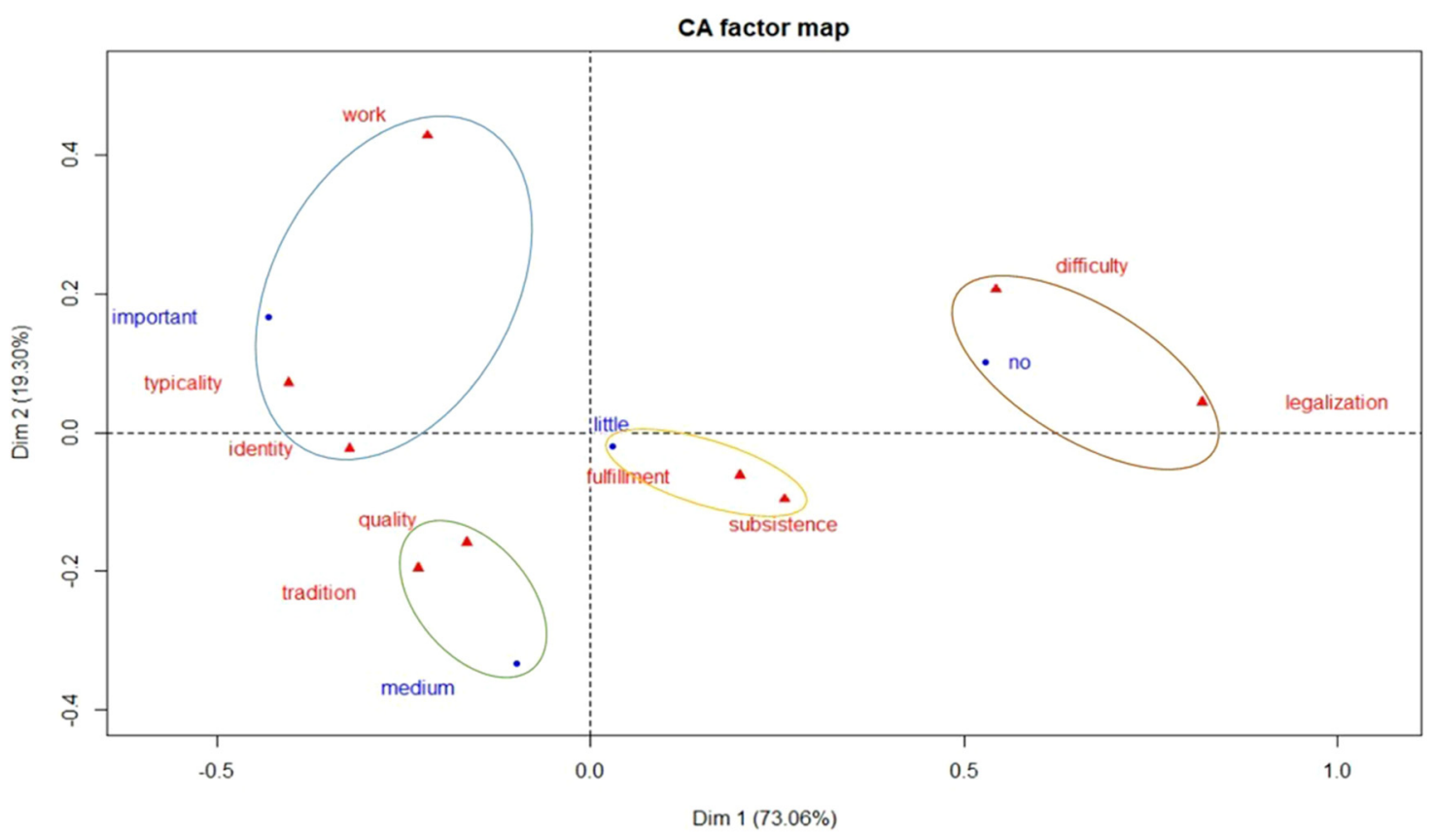

Fig. 2. Social representation of the Serrano cheese producer identity according to their level of involvement in collective action.

Fig. 2. Représentation sociale de l'identité des producteurs de fromage Serrano en fonction de leur degré d'implication dans l'action collective.

category also highlighted the efforts and devotion needed to realize their activity. Moreover, we observed that complying with the standards for the SIM certification is important for this group of producers. Indeed, seven families among the twelve of the sample having the SIM certification and three of the five in process of SIM certification belong to the "important" category. So, for this group, their investment in collective action to valorize the production to the market is higher than the others. Then, for the moderately involved families, the traditions and the sanitary quality appeared central in their representation. For this group, cheese production is also important, but to a lesser extent, their engagement is smaller. There is no SIM certified production and only two are in the process of SIM certification in this category. After that, for the little involved producers we saw that the fulfillment was high, but they considered the cheese production as a subsistence activity. The beef production is considered to be the most profitable activity. Producers not involved in associations have a bad representation of their identity as Serrano cheese producers. They brought forward the difficulties and legalization problems. This discouragement does not stimulate them to engage in collective action. They rely on the beef production activity. Similarly, Michel-Guillou and Ehrlich (2005), who linked farmers'social representations to their practices and position statements, showed that the most constrained farmers (e.g. dairy farmers) mainly referred to their work in terms of disadvantages.

Nonetheless, we observed that the feeling of belonging to territory was high for most of the producers, regardless of their level of involvement in collective action. However, results obtained from the word association did not show that the territory was a central component of the Serrano cheese producers' identity for the producers moderately, little and not engaged; whereas it was more important for producers a lot engaged. Indeed, references to territory were more relevant in this category of producers, in which for example, they cited seven times natural pastures. Moreover, these producers also cited references linked to cheese typicality and to producers' identity next to the references to territory. These three dimensions gather the specificities of LAS based on the relationship between human/territory/product. This social representation, if shared by all the categories of producers, could support the development of common projects for the defense and the valorization of the cheese with higher engagement.

However, previous studies found that the extension services were the driver of collective action as they created the producer associations and they are central to their functioning (e.g. organization of the meetings). Collective action was built up on a top-down process, in which the producers were generally little involved. This could be a reason for the general weak participation from the producers in associations and the small number of members (Pachoud et al., 2019). Vitrolles (2011) demonstrated also the topdown approach concerning the process of certification for the protected designation of origin (PDO) "Campos de Cima da Serra". Indeed, the extension services delimited the production area by the soil and climate conditions and defined the characteristics of the cheese and the process. The result was that the PDO appeared to be little understood by the producers. The present study showed that those producers who were highly active in the associations obtained the SIM certification to legally sell their cheese in municipal markets. In this sense, it signals the willingness to enter the formal market. But, producers often highlighted that certification standards change the traditional characteristics of the Serrano cheese, although the discussion for a recognition of the specificities of artisanal production in regulation in Brazil became central the last decade (Wilkinson et al., 2016). 
In sum, the study brought interesting findings on the link between representation of identity, feeling of belonging and collective action in LAS. However, as literature on this topic is missing, further studies are needed. Indeed, research on social representation seems to be a promising tool to engage discussion between actors and to find solutions to issues in the field of collective action and cooperation in LAS. In fact, the convergence toward common representations of their identity and their activity would facilitate the definition of common objectives and the implementation of projects.

\section{Conclusion}

The content of the social representation of the identity of Serrano cheese producers reflected their participation in collective action. For producers who put the typicality of the Serrano cheese, the territory and the producers' identity at the center of their representation, they were highly engaged in collective action for the valorization and the defense of the cheese. Producers who put the difficulties of the profession and legalization issues forward did not participate in collective action. Nevertheless, all the categories of producers showed a high attachment to their territory, although the territory was not a central component of their identity's representations, except for the producers a lot engaged. Thus, a discussion among the different producers' categories of social representations, based on the strong feeling of belonging, appears valuable in the objective to converge toward common representations to favor collective action. The representation of the producers a lot engaged based on references to the territory, the product and the producers' identity seems to be the most promising representation to obtain a high engagement in collective action for cheese valorization. However, actual collective action demonstrated a top-down process led by the extension services, in which producers were little involved. This could have significant risk for the traditional cheese and know-how, as valorization projects may lead to a standardization of the cheese and industrialization of the process, as showed for the PDO certification. In this sense, there is an urgent need to integrate the producers in collective action through a more participatory governance, in order to build common representations between the actors of the LAS. This would definitively lead to more efficient projects for the defense and the valorization of the Serrano cheese.

\section{References}

Abric JC. 1994. Pratiques sociales et représentations. Paris: PUF, $251 \mathrm{p}$.

Abric JC. 2003. La recherche du noyau central et de la zone muette des représentations sociales. In: Abric JC, ed. Méthodes d'étude des représentations sociales. Ramonville Saint-Agne: Erès, pp. 59-80.

Ambrosini L. 2007. Sistema agroalimentar do Queijo Serrano: estratégia de reprodução social dos pecuaristas familiares dos Campos de Cima da Serra-RS. Mémoire de Master en développement rural, Universidade Federal do Rio Grande do Sul, Porto Alegre, $196 \mathrm{p}$.
Brunet R. 1990. Le territoire dans les turbulences. Montpellier: Reclus, $224 \mathrm{p}$.

Brunet R, Ferras R, Théry H. 1992. Les mots de la géographie. Paris : Reclus-La Documentation française, $518 \mathrm{p}$.

Cañada JS, Muchnik J. 2011. Introduction: ancrage et identité territoriale des systèmes agroalimentaires localisés. Économie rurale 322: 4-10.

Chalas Y. 2009. De la trajectoire épistémologique récente du concept de territoire. In: Vanier M, ed. Territoires, territorialité, territorialisation. Controverses et perspectives. Rennes: PUR, pp. 177-180.

Cruz FT. 2012. Produtores, consumidores e valorização de produtos tradicionais: um estudo sobre qualidade de alimentos a partir do caso do queijo serrano dos Campos de Cima da Serra-RS. Thèse de doctorat en développement rural, Faculdade de Ciências Econômicas, Universidade de Federal do Rio Grande do Sul, Porto Alegre, 292 p.

Di Méo G. 1998. Géographie sociale et territoires. Paris : Nathan, $320 \mathrm{p}$.

Di Méo G. 2008. Une géographie sociale entre représentations et action. Montagnes méditerranéennes et développement territorial 23: $13-21$.

Di Méo G. 2014. Introduction à la géographie sociale. Paris : Armand Colin, $189 \mathrm{p}$.

Di Méo G. 2016. Le désarroi identitaire. Une géographie sociale. Paris: L'Harmattan, 216 p.

Di Méo G, Buléon P. 2005. L'espace social. Lecture géographique des sociétés. Paris : Armand Colin, 304 p.

Ehrlich M, Dervin C. 1999. Une étude expérimentale : l'origine de la motivation, la signification symbolique attachée aux biens par les consommateurs. Les cahiers de l'IUT numéro spécial: 15-35.

Ehrlich M, Alvarez L, Dervin C. 1997. Communication technicoscientifique, pratiques de production, transfert de connaissances et rôle des représentations sociales en conseil agricole. In : Ehrlich M, Rouleau S, eds. Actes du colloque en psychologie sociale: développement technoscientifique, agriculture \& sciences sociopsychologiques. Paris: INA P-G, pp.29-56.

Flament C. 1987. Pratiques et représentations sociales. In : Beauvois JL, Joule RV, Monteil JM, eds. Perspectives cognitives et conduites sociales. Tome 1 : théories implicites et conflits cognitifs. Cousset : Delval, pp. 143-150.

Flament C. 1994. Structure, dynamique et transformation des représentations sociales. In: Abric JC, ed. Pratiques sociales et représentations. Paris: Presses Universitaires de France, pp. 37-57.

Fournie S. 2016. Construction sociotechnique et relationnelle d'une gouvernance alimentaire territoriale. Thèse de doctorat en sociologie, Institut agronomique, vétérinaire et forestier de France, Paris, 349 p.

Fournier S. 2008. Les indications géographiques: une voie de pérennisation des processus d'action collective au sein des systèmes agroalimentaires localisés? Cahiers Agricultures 17(6): 547-551. DOI: 10.1684/agr.2008.0250.

Husson F, Josse J, Le S, Mazet J. 2018. FactoMineR: Multivariate exploratory data analysis and data mining with R.R package version 1.41. [2019/04/15]. http://CRAN.R-project.org/package= FactoMineR

IBGE. 2018. Conheça cidades e estados do brasil. [2019/04/23]. https://cidades.ibge.gov.br/.

Jodelet D. 1989. Les représentations sociales. Paris : PUF, 454 p.

Kiesler CA. 1971. The psychology of commitment: Experiments linking behavior to belief. New York: Academic press, $190 \mathrm{p}$. 
Lopez E, Muchnik J. 1997. Petites entreprises et grands enjeux : le développement agroalimentaire local. Paris : L'Harmattan, $716 \mathrm{p}$.

Marshall G. 1998. A dictionary of sociology. New-York: Oxford University Press, $710 \mathrm{p}$.

Michel-Guillou E, Ehrlich M. 2005. Proximité d'appartenance mentale des individus. Les réseaux de relations professionnelles dans l'agriculture. In: Torre A, Filippi M, eds. Proximités et changements socio-économiques dans les mondes ruraux. Paris: Quæ, pp. 215-233.

Moliner P. 1993. Cinq questions à propos des représentations sociales. Cahiers internationaux de psychologie sociale 20: 5-14.

Moliner P. 2001. La dynamique des représentations sociales. Grenoble: Presses Universitaires de Grenoble, $250 \mathrm{p}$.

Moliner P, Joule RV, Flament C. 1995. Essai contre-attitudinal et structure des représentations sociales. Cahiers internationaux de psychologie sociale 27: 44-55.

Muchnik J. 1996. Systèmes agroalimentaires localisés : organisations, innovations et développement local. Proposition issue de la consultation du Cirad «Stratégies de recherche dans le domaine de la socio-économie de l'alimentation et des industries agroalimentaires ». Doc. Cirad 134(96): 27.

Muchnik J, Sanz-Cañada J, Torres-Salcido G. 2008. Systèmes agroalimentaires localisés: état des recherches et perspectives. Cahiers Agricultures 17(6): 513-519. DOI: 10.1684/ agr.2008.0251.

Pachoud C, Labeyrie V, Polge E. 2019. Collective action in localized agrifood systems: An analysis by the social networks and the proximities. Study of a Serrano cheese producers' association in the
Campos de Cima da Serra/Brazil. Journal of Rural Studies. DOI: 10.1016/j.jrurstud.2019.10.003.

Pecqueur B. 2009. De l'exténuation à la sublimation : itinéraire d'une notion et de ses déclinaisons. In: Vanier M, ed. Territoires, territorialité, territorialisation. Controverses et perspectives. Rennes : PUR, pp. 205-209.

Presidency of the Republic of Brazil. 1950. Lei $\mathrm{n}^{\circ} 1.283$, de 18 dezembro de 1950. Dispõe sobre inspeção industrial e sanitária dos produtos de origem animal. Presidência da República, Casa Civil, Brasilia.

Presidency of the Republic of Brazil. 1952. Decreto ${ }^{\circ}$ 30.691, de 29 de março de 1952. Aprova o novo Regulamento da Inspeção Industrial e Sanitária de Produtos de Origem Animal. Presidência da República, Casa Civil, Brasilia.

Raffestin C. 1982. Remarques sur les notions d'espace, de territoire et de territorialité. Espaces et sociétés 41: 167-171.

Vieira F, Dortzbach D. 2017. Caracterização ambiental e delimitação geográfica dos Campos de Cima da Serra. Florianópolis: Epagri, $72 \mathrm{p}$.

Vitrolles D. 2011. When geographical indication conflicts with food heritage protection. Anthropology of food 8. DOI: 10.4000/ aof.6809.

Wilkinson J, Cerdan C, Dorigon C. 2016. Indicações geográficas e produto de origem no Brasil: instituições e redes em ação recíproca. In: Wilkinson J, Niederle PA, Mascarenhas GCC, eds. O sabor da origem: produtos territorializados na nova dinamica dos mercados alimentares. Porto Alegre: Escritos do Brasil, pp. 73-106.

Cite this article as: Pachoud C. 2019. Identity, feeling of belonging and collective action in localized agrifood systems. Example of the Serrano cheese in the Campos de Cima da Serra, Brazil. Cah. Agric. 28: 28. 